\title{
Around Baikal: on the causes of ecological problems
}

\author{
Leonid Korytny, and Olga Gagarinova* \\ V.B. Institute of Geography SB RAS, Ylan-Batorskay 1, 664033, Irkutsk, Russia
}

\begin{abstract}
This paper is devoted to the unique water body, Lake Baikal, the largest freshwater reservoir by volume in the world that was included on the list of UNESCO World Heritage Sites and is regulated by the federal law of its protection. The global role of Baikal as a strategic reserve of water resources of the highest class is increasing in importance. Furthermore, Lake Baikal and its surroundings are invariably the focus of ecological problems. The most challenging issues are the lake's water pollution leading to changes in hydrobiocenoses, soil and vegetation digression in areas of increased recreational load, forest fires causing a decrease of the number of rare species of flora and fauna, etc. Imperfection of the legal framework, the lack of a unified managerial center and the attempts to deal with the problems solely at the federal level involve a number of incompetent decisions on the lake level regulation and on the setting of its water-protection zone. The conflicts of the interests of the subjects of the federal and regional levels in issues related to use and the protection of natural resources present serious obstacles to the development of a unified, ecologically oriented strategy of economic development of the territory. For a successful solution of the current challenges it is necessary to recognize the ecological problems of Lake Baikal as the priority concerns throughout the country, optimize management of the socio-economic development of the Baikal natural territory on the basis of nature-conservation principles by ensuring appropriate funding, develop a unified scheme of comprehensive monitoring of the ecological and sanitary-hygienic status of Lake Baikal and its protection zone, improve the system of scientific research on the Baikal natural territory, introduction ubiquitous ecological training and education of the population, organize the waste and effluent treatment system in accordance with the latest international technologies, etc.
\end{abstract}

\section{Introduction}

The unique features of Lake Baikal make it a special natural site of the planet Earth. The freshwater reserve in the lake is 23.6 thousand cubic meters, or $20 \%$ of the freshwater reserves of all lakes in the world and $5.5 \%$ of the planet's highest-quality and purity freshwater. The self-purification mechanisms of Baikal have no equal as they make its water almost distilled and saturated with oxygen, with low content of mineral salts and

*Corresponding author: whydro@irigs.irk.ru 
organic matter. Baikal is the only deep freshwater lake, the life in which is traceable to the very bottom; the lake is unique in having a peculiar flora and fauna, and the diversity and degree of endemism of species inhabiting it.

Since 1966, Baikal and its coastal territory have utilized the status of UNESCO World Natural Heritage Site as an example of a remarkable freshwater ecosystem in Russia and throughout the world. The law "On the protection of Lake Baikal" was adopted in 1999, Russia's only law of a federal level for a regional site [1]. Baikal is a strategic reserve of water resources, the global value of which is constantly increasing in view of the overall reduction in the volumes of clean water in the world. Lake Baikal has a huge hydropower potential, is the world's well-known natural laboratory and serves as a "magnet" for tourists from all over the world.

However, the lake and the territory surrounding it are always in the center of ecological problems and ecological discussions, both in this country and abroad, and the challenges are constantly increasing. The most acute issues are:

- the danger that waste products from the Baikalsk Paper and Pulp Plant, accumulated during several decades, can enter the lake;

- the pollution of the coastal waters, causing a dramatic growth of filamentous algae (spirogyras) in shallow water, the emergence of toxic green algae and changes in hydrobiocenoses;

- a "mess" in the boundaries of property, in the water-protection zone and on specially protected natural areas, in municipalities and in settlements;

- the transformation of landscapes, soil and vegetation digression in areas of increased recreational pressure;

- forest fires on the territories of national parks and nature reserves;

- a decrease of the number of rare species of flora and fauna.

\section{The causes of the Baikal ecological problems}

\subsection{Natural factors}

They include primarily a high vulnerability, friability, and a low natural resistance of many natural geosystems in the areas surrounding Baikal, especially the steppe and steep-slope landscapes. The most hazardous slopes as regards the emergence of extreme gravitational processes (rock slides, avalanches and debris flows) are the southeastern slopes of Baikal Range and the northwestern slopes of the Khamar-Daban Range which are adjacent to the lake shore. Global changes of climate manifested themselves on the Baikal natural territory as a trend for a rise of air and coastal water temperature, especially in the wintertime, which, in turn, led to a change in the ice regime and in the conditions of functioning of the biota. More specifically, omul move away from the shores; there is an increase of the number of separate species of organisms, such as filamentous algae as well as an improvement in the reproduction conditions for a number of intruders, including Canadian waterweed (Elodea canadensis). This appears to be also responsible for the increase of the number of "dry thunderstorms", the main cause of fires in hard-to-access and protected territories. The low precipitation amount during 2014-2019 was responsible for a low water level within the Lake Baikal drainage basin and for the decrease of the lake level that involved a large number of problems. And, finally, forest diseases are escalating; this especially refers to the Siberian stone pine forests; many thou ha of forest are infested with Siberian silkworm and bacterial dropsy (this disease has now covered more than 50 thou ha). 


\subsection{Anthropogenic factors}

The main factor is the pollution of the coastal waters by organic compounds, microorganisms and heavy metals transported to the lake by the river runoff, primarily by the Selenga river; by the inadequately treated (or not treated at all) wastewaters from settlements and tourists camps located on Baikal's shores, and by discharges of bilge waters from small-size ships. Such a situation is caused by a poor operation and lack of waste treatment facilities. In the Central Ecological Zone of the Baikal Natural Territory (CEZ BNT), only two out of the thirty waste treatment facilities in operation discharge standard effluents; most of the production installations do not have any treatment facilities at all; this is also true in regard to the berthing facilities receiving waste from ships. The existing situation is associated not only with a shortage of funding but also with the fact that there are currently no technologies suitable to Lake Baikal.

Forest fires have been doing enormous damage in recent years. In this case, the role of the "human factor" is important not only as the frequent cause of fires on actively visited territories but also from the perspective of a poor monitoring and, especially, a chronic delay with the organization of fire-fighting, and imperfection of this organization itself. This is one of the chief causes for a reduction in biological diversity of the flora and fauna, primarily rare species, which is also aggravated by poaching.

Numerous aspects characterize the problem of recreational territories, although the priority of tourism organization at Baikal is beyond any doubt. The negative factors include: an increase in recreational loads; littering of the coastal belt and WPZ, primarily in places of unorganized recreation; disturbances to the road network in steppe and foreststeppe landscapes in the coastal areas, and the absence of a centralized system for collection of wastes and wastewaters.

\subsection{Legal collisions}

A large number of problems are caused by gaps in legislation, largely at the federal level, which involve vagueness and confusion in the legal field and serious consequences. There are ongoing disputes over the ownership and boundaries of tracts of land between municipalities, specially protected natural areas and private holdings resulting in judicial proceedings.

An example of a gross incompetence was provided by the Decree of the RF Government adopted in 2001 stating that it was necessary to "keep" the Baikal level within a one-meter prism, between the marks of 456 and $457 \mathrm{~m} \mathrm{[2].} \mathrm{As} \mathrm{long} \mathrm{as} \mathrm{the} \mathrm{volumes} \mathrm{of}$ water inflow to the lake were close to normal, this was possible to do with great difficulty by regulating discharges through the Irkutsk Hydroelectric power station (HES) dam located on the Angara river flowing out from Baikal. But when in 2014 there occurred the low-water level conditions caused by extremely low precipitation amounts within the Baikal drainage basin, the decrease of the level below the mark of $456 \mathrm{~m}$ was only possible to stop by exposing the water intakes downstream of Irkutsk HES so that several hundreds of thousands of people would become devoid of water resources; of course, this was inacceptable. Therefore, Baikal was graciously "allowed" to temporarily decrease below the level established by the Government, by way of exception only, and that Decree recognized as wrong was not canceled. The dramatic situation with the low water level lasted until 2018 when the lake level began to rise. It is not inconceivable that the high water level phase can set in soon, and the problems will arise with the exceedance of the level at the mark of $457 \mathrm{~m}$. Furthermore, the absence of judicious Decree foreseeing variants of the lake's water level fluctuations in conditions of high and low water presets an 
obstacle to adopting the Regulations of use of the water resources in the reservoirs of the Angara cascade.

An illustrative situation is with the establishment of the boundaries of the waterprotection zone (WPZ) of the lake. According to the Water Code of the Russian Federation (2007), for an especially valuable and unique site, Lake Baikal, there is a need to develop an individual project of WPZ regulated by the federal law "On the protection of Lake Baikal" [1,3]. However, the lake had lacked any WPZ in the past. In 2015, the Government of the Russian Federation approved the boundaries of the zone by combining it with CEZ BNT. The system of legal regulations and restrictions of WPZ was extended to the territory of 50 thou $\mathrm{km}^{2}$, with the population of about 130 thou people living on it. The territory thus identified became subject to the restrictions of two nature-conservation regulations: CEZ BNT and WPZ. In addition to the list of prohibitions of the economic and other kinds of activities doing damage to the lake ecosystem in CEZ BNT, a number of restrictions for WPZ were added:

- activity on maintenance of the existing production and consumption waste disposal areas;

- arrangements of cemeteries and burial grounds for animal refuse;

- traffic and parking of transport vehicles on unsurfaced roads;

- prohibition of prospecting and extraction of commonly occurring mineral resources for separate categories of users, etc.

As a result of the inclusion of an unjustifiably large territory in WPZ, there emerged additional legal, social and economic problems instead of the expected positive effect. For purposes of remedying the situation, V.B. Sochava Institute of Geography SB RAS prepared in 2017-2018 the WPZ project according to the assignment of the Ministry of natural resources RF; it included the scientific substantiation and the description of the WPZ boundary, cartographic material at a scale of 1:200 000, and the list of geographical coordinates of its turning points. The scientific substantiation and the methodology of establishing the water-protection zone are based on the approach developed by the Siberian Landscape-Geographical School $[4,5,6]$. In accordance with the landscape-hydrological principles, WPZ should include all territories from which the runoff is drained into Lake Baikal, including the catchments of first-order rivers, the coastal meadow-and-bog complexes and dark-coniferous landscapes with high water-protection properties, and steep slopes of the coast experiencing extreme hydrological-geomorphological processes. For the coastal areas of Lake Baikal characterized by considerable economic and recreational development, it is necessary to prepare individual projects of water-protection zoning, in accordance with the plans of existing and envisioned territorial development. Within the boundaries of municipal entities, the WPZ project is substantiated individually on the basis of the natural conditions and characteristics of economic development. According to results of this project, the Lake Baikal WPZ boundaries were approved in 2019; however, it was a partial solution, because in settlements and recreation zones the width of WPZ was equated with the coastal protection belt and was $200 \mathrm{~m}$ from the lake's edge line [7].

\subsection{Management problems}

Sustainable socio-economic development of the territory with a special modality of nature management: the Lake Baikal drainage basin, along with the entire Baikal region, is possible only with optimal ecological-economic management of the entire territory. This is not the case, however; hence, the contradictions between different levels of authorities and the population are increasing. In particular, this manifests itself in the departmental and territorial fragmentation of the monitoring operations, and in the incompleteness of information regarding use of water resources and water diversion. The expectations of the 
creation of Schemes for integrated use and protection of water bodies (Russian acronym: SKIOVO) have not been met; they were prepared within the boundaries of enlarged watereconomy areas and were not combined into a unified scheme for the entire lake drainage basin, which makes their utilization difficult; more important, however, the mechanism for funding the activities has not yet been determined. As a result, considerable funds of targeted water-protection and, in general, environmental programs for the Lake Baikal drainage basin were spent in a far from satisfactory manner.

The Baikal region is characterized by considerable contradictions between the federal subjects of Russia as regards the priorities of use and protection of natural resources. The hydropower priority is the top priority for Irkutsk oblast, because its economy is built on the country's lowest tariffs for energy consumption. And Irkutsk oblast would not share its profits with the Republic of Buryatia. The environmental restrictions for Buryatia, with most of its territory lying within the Lake Baikal drainage basin, present serious obstacles to the economic activities; therefore, the population of the republic is exquisitely sensitive to any situations around the lake, such as those which are associated with water level fluctuations or changes in the boundaries of the water-protection zone. Noteworthy is the fact that the authorities of the oblast and the republic have not yet agreed to establish any common specially protected natural areas and it was not until 2019 that they agreed on the Rules for touristic-recreational activity.

\section{Conclusions and solutions}

For the successful solution of the problems facing Lake Baikal, it is necessary to:

- recognize the ecological problems of Lake Baikal as the priority challenges on a national scale and ensure appropriate funding, and the best approach to be used would be at the level of national projects;

- eliminate the legal "lacunas" through a systemic correction of documents at the federal and regional levels, including normative indicators with due regard for the natural characteristics of the lake;

- select the suitable (for Baikal) ecologically effective and economically accessible technologies of wastewater treatment, solid waste management, collection of bilge waters from ships, etc.;

- organize the economic and recreational activities in the areas surrounding Baikal on the principles of a "green economy" by ensuring a high rate of employment and a high quality of life of the local population;

- carry out territorial planning of the areas surrounding Baikal on the basis of the principles of landscape planning, including a correction of the boundaries of the waterprotection zone in settlements;

- unify uncoordinated departmental observational networks and their observational data, and create the system of comprehensive monitoring;

- continue scientific research into the ecosystems of Baikal and the areas surrounding it on the basis of the latest international techniques and instrumental support;

- ensure continuous ecological training and education as well as the propaganda of environmental values and nature management culture among the region's population and tourists;

- organize systematic work in mass media and on the Internet with the purpose of familiarizing the international and Russian community with the special role of the unique lake and providing true information on its present status and the ecological problems facing it in order to improve the image of Baikal and create preconditions for increasing the investment and tourist flows; 
- considerably improve management of the socio-economic development of the Baikal natural territory having regard to the nature-conservation priorities and ecological restrictions by foreseeing optimal conformity of the federal and regional levels.

Comprehensive ecological atlases of the Baikal region can become the basis for solving the ecological problems of the Baikal region. One such atlas in the electronic and printed versions [8] was published in the Russian, English and Mongolian languages. Work is being underway on the preparation and publication of the atlas entitled "The Baikal region: society and nature", a product of a new type which integrates currently available information on the impact of socio-economic processes on the natural environment at different spatial levels: from microregional and regional to municipal and local. The thematic contents of the maps will be distributed in three thematic directions: 1) socioeconomic factors responsible for the ecological situation; 2) ecological status and transformation of the natural environment, and the medical-geographical situation, and 3) environmental protection and environmental sound management.

This research was done with the support from the Russian Foundation for Basic Research, project № 17-29-05043.

\section{References}

1. Federal law of 01.05.1999 No. 94-FZ On Protection of Lake Baikal (with changes 28.06.2014 181-FZ - [URL]: www.pravo.gov.ru (Accessed 10.01.2020)

2. Decree of the RF Government of 26.3.2001 no. 234 "On limiting values of the water level in Lake Baikal in carrying out the economic and other activities [URL]: http:www.poisk-zakona.ru/154378.html (Accessed 10.01.2020)

3. Water Code of the Russian Federation dated 03.06.2006 No. 74-FZ [URL]: http://www.consultant.ru/document/cons doc_LAW 60683/ (Accessed 10.01.2020)

4. A.N. Antipov, V.N. Fedorov Landscape hydrological organization of the area (Novosibirsk: Publishing House of Siberian Branch of the Russian Academy of Sciences, 2000)

5. A.N. Antipov, O.V. Gagarinova Water protection zoning to ensure the protection regime of valuable water bodies, Water protection zones: practical experience and feasibility of development (M: Publishing house NIA-Priroda) pp. 61-71 (2006)

6. A.N. Antipov, L.M. Korytny, Voprosy Geografii, v. 133, pp. 32-47 (2012)

7. The Russian Government's Executive Order No. 507-p of 26.03.2018 On Introducing Amendments to the Annex to the Russian Government's Executive Order No. 368-p of 5.03.2015

$$
\text { [URL]: }
$$

http://static.government.ru/media/files/ YPvFgDasQJudMdysTCNiiaRWA6bZuBB0.pdf (Accessed 10.01.2020)

8. A.R. Batuev (ed.), L.M., Korytny (ed.) Ecological Atlas of the Lake Baikal Basin (Irkutsk: Publishing House of Institute of Geography SB RAS, 2015) 